\title{
Optimasi Ekstraksi DNA Genomik Probiotik Lactobacillus plantarum IIA-1A5 dari Daging Sapi Peranakan Ongole untuk Sekuensing Genom Utuh
}

\author{
Optimization of Genomic DNA Extraction of Lactobacillus plantarum IIA-1A5 Probiotic from Ongole Grade \\ Cattle for Whole Genome Sequencing \\ C. Budiman, I. I. Arief \& M. Yusuf \\ Departemen Ilmu Produksi dan Teknologi Peternakan, Fakultas Peternakan, Institut Pertanian Bogor \\ Email koresponden author: cahyo@ipb.ac.id
}

\begin{abstract}
Lactobacillus plantarum IIA-1A5 is an Indonesian probiotic bacterium isolated from Ongole grade cattle. This strain has demonstrated series of benefical properties and promising to be further applied in development of functional foods. Attempts to further exploit this strain require comprehensive understanding on its molecular properties, in particular is the genes responsible for its probiotic properties. Whole genome sequencing (WGS) is currently an affordable tool to fully decipher genetic organization of the bacteria, yet often limited by the requirement of high amount of high quality of genomic DNA of sample. This study aims to develop an optimum method for obtaining high quality genomic DNA of L. plantarum IIA-1A5 in sufficient amount of WGS study. To address, genomic DNA of L. plantarum IIA1 A5 was extracted from growth phase of adaptation, exponential and stationary. The result showed that exponential and stationary phases were able to yield genomic DNA higher than minimum requirement for WGS. Nevertheless, the quality of genomic DNA from both phases were considerably low, according to their 260/280 and 260/230 ratio. The worst quality was found on 260/280 ratio referring to the presence of high amount of proteinaceous compounds in the sample. Further optimization was done on genomic DNA from stationary phase by adding proteinase $\mathrm{K}$ at various incubation time. It showed that the incubation for 7.5 to 10 hours yielded acceptable purity and amount of genomic DNA for WGS. In addition, we also observed a trade-off phenomenon of yield-purity genomic DNA of L. plantarum IIA-1A5. Altogether, the optimized method here should contribute to further molecular studies of this probiotic strain.
\end{abstract}

Keywords: genomic DNA, Lactobacillus plantarum IIA-1A5, probiotic, whole genome sequencing

\section{PENDAHULUAN}

Pemanfaatan probiotik dalam pemenuhan kebutuhan pangan fungsional di tengah masyarakat semakin meningkat. Probiotik didefinisikan sebagai kelompok mikro-organisme yang jika dikonsumsi dalam jumlah yang memadai bisa memberikan efek positif bagi kesehatan inangnya (FAO/WHO, 2002). Kelompok bakteri probiotik paling banyak digunakan dalam aplikasi industri adalah golongan Lactobacillus dan Bifidobacteria, yang merupakan anggota dari kelompok bakteri asam laktat (BAL) (Siezen dan Wilson, 2010). Nilai pasar probiotik secara global pada tahun 2017 mencapai lebih dari USD 45 miliar dan diprediksi akan terus meningkat hingga USD 64 milar pada tahun 2022 (Statista, 2017). Lebih jauh, ada lebih dari 200 paten terkait komersialisasi probiotik di dunia sejak 1981 (Siezen dan Wilson, 2010).

Meskipun demikian, pasar probiotik di Indonesia dipenuhi oleh probiotik non lokal, beradasarkan asal isolasinya. Beberapa probiotik lokal sudah diisolasi dari berbagai sumber, tetapi sejauh ini belum ada yang dikembangkan hingga ke tahap industri. Salah satu strain lokal probiotik adalah Lactobacillus plantarum IIA-1A5 yang diisolasi dari daging sapi Peranakan Ongole (Arief et al., 2013; Arief et al., 2015a). Bakteri ini memproduksi bakteriosin plantarisin IIA-1A5 yang bisa menghambat bakteri patogen dari kelompok Gram negatif dan positif (Arief et al., 2013), yang diduga melalui mekanisme aksi bakterisidal (Arief et al., 2015b). Sifat probiotik bakteri ini telah dikonfirmasi oleh Arief et al. (2015a), antara lain meliputi ketahanan terhadap $0.5 \%$ asam empedu dan kemampuan koagregasi terhadap beberapa bakteri patogen, termasuk Escherichia coli ATCC 25922, Salmonella typhimurium ATCC 14028, Escherichia coli/EPEC and Staphylococcus aureus ATCC 25923.

Meskipun banyak penelitian yang telah dilakukan pada probiotik lokal, akan tetapi penelitian secara komprehensif pada aspek molekuler probiotik lokal belum banyak dilakukan. Lebeer et al. (2008) menyatakan bahwa kajian molekuler secara komprehensif pada probiotik 
diperlukan untuk dua tujuan. Pertama, menentukan kondisi terbaik yang bisa mendorong probiotik tersebut menampilkan performa terbaiknya. Kedua, proses seleksi strain probiotik baru berdasarkan kriteria-kriteria molekuler tertentu. Kajian molekuler pada probiotik juga bisa membuka rangkaian gen-gen penting yang terlibat pada performa positif probiotik tersebut dan dimanfaatkan pada berbagai aplikasi (Azcarate-Peril et al., 2009). Kajian molekuler pada $L$. plantarum IIA-1A5 sejauh ini hanya terbatas pada penentuan sekuens 16s rRNA (Arief et al., 2015a) dan gengen yang terlibat dalam produksi bakteriosin (Arief et al., 2015b).

Salah satu kajian molekuler yang berkembang pesat pada dekade ini adalah penentuan urutan keseluruhan DNA (whole genome sequencing/WGS) dari suatu organisme. Perkembangan teknologi yang sangat pesat dalam dua dekade mendorong penurunan biaya sekuensing secara ekstrim. Hal ini mendorong kajian WGS suatu bakteri menjadi pekerjaan yang sangat memungkinkan untuk dilakukan (Shendure dan Ji, 2008; Land et al., 2005). Dibandingkan dengan teknik WGS yang digunakan pertama kali untuk bakteri (Fleischmann et al., 1995; Fraser et al., 1995), teknologi sekarang memiliki efisiensi jauh lebih tinggi dari sisi waktu dan biaya (Land et al., 2005). Lebih jauh, Siezen dan Wilson (2010) melaporkan WGS dari beberapa bakteri probiotik sudah tersedia. Kelompok bakteri probiotik yang paling banyak dikaji dari sisi WGS adalah probiotik yang berkaitan dengan kesehatan saluran pencernaan.

Secara spesifik, WGS pada kelompok probiotik bisa memberikan informasi komprehensif tentang regulasi genetik dalam proses produksi bakteriosin. Detail mekanisme regulasi tersebut sejauh ini masih diperdebatkan dan melibatkan banyak gen dalam bakteri tersebut. Arief et al. (2015b) sebelumnya melaporkan bahwa produksi setidaknya melibatkan gen $P \ln A, P \ln B$ dan $P \ln E F$. Meskipun demikian, kaitan gen-gen tersebut dan kemungkinan pendekatan WGS pada $L$. plantarum IIA-1A5 memungkinkan untuk bisa menjawab isu tersebut.

Salah satu kendala dalam kajian WGS adalah dibutuhkannya sampel DNA dalam jumlah dan kualitas yang tinggi (Zhu et al., 2016). Sim et al. (2015) lebih jauh mengungkapkan bahwa titik kritis untuk mendapatkan sampel DNA yang memenuhi syarat tersebut adalah pada proses ekstraksi. Meskipun kit untuk ekstraksi DNA dari sampel sudah tersedia dari berbagai perusahaan, optimasi kondisi ekstraksi masih tetap diperlukan. Panova et al. (2016) dan Salva-Serra et al. (2018) menambahkan bahwa setiap organisme, termasuk bakteri, memiliki karakteristik molekuler yang berbeda, sehingga metode optimum untuk setiap jenis bakteri juga bisa berbeda.

Penelitian ini bertujuan untuk mengoptimasi metode ekstraksi DNA genomik dari L. plantarum IIA-1A5 untuk keperluan WGS. Standar kuantitas dan kualitas DNA genomik yang digunakan dalam penelitian ini adalah long read WGS platform dari PacBio dengan menggunakan SMRT cell technology.

\section{MATERI DAN METODE}

\section{Penyegaran dan Pembiakan Kultur L. plantarum IIA- $1 \mathrm{A5}$}

Proses penyegaran dan pembiakan L. plantarum IIA1A5 dilakukan dengan mengacu pada Arief et al. (2013) dan Mutmainna (2017). Proses penyegaran dilakukan dengan menumbuhkan $10 \%(\mathrm{v} / \mathrm{v})$ L. plantarum IIA-1A5 dari stock culture di dalam media De Man, Rogosa and Sharpe (MRSB) segar. Kultur kemudian diinkubasi pada suhu $37^{\circ} \mathrm{C}$ selama 24 jam, proses penyegaran ini dilakukan sebanyak 3 kali. Kultur yang sudah disegarkan tersebut kemudian digunakan untuk proses kultivasi berikutnya.

\section{Kurva Pertumbuhan L. plantarum IIA-1A5}

Kurva pertumbuhan L. plantarum IIA-1A5 dianalisis berdasarkan Silva et al. (2018) dengan menumbuhkan 10\% (v/v) bakteri tersebut pada media MRSB. Densitas sel diukur dengan menggunakan UV-Vis spectrophotometer pada panjang gelombang $600 \mathrm{~nm}$ pada beberapa interval waktu yang berbeda.

\section{Ekstraksi DNA Genomik dari Fase Pertumbuhan yang Berbeda}

Pemanenan pada berbagai fase dilakukan dengan menggunakan sentrifugasi pada suhu $4{ }^{\circ} \mathrm{C}$ dengan kecepatan 8000 g. Sel kemudian dicuci dengan $0.8 \% \mathrm{NaCl}$ fisiologis sebanyak dua kali sebelum proses ekstraksi. Ekstraksi DNA genomik kemudian dilakukan dengan menggunakan QIAamp DNA mini Kit (Qiagen, USA) berdasarkan protokol dari perusahaan. Secara ringkas, sel (dari $100 \mathrm{~mL}$ kultur) yang sudah dipanen diresuspensi dalam bufer ATL sebanyak 180 ul dan ditambahkan proteinase K sebanyak 20ul, kemudian dihomogenkan dengan vorteks. Campuran kemudian diinkubasi selama 2 jam pada suhu $56{ }^{\circ} \mathrm{C}$ dengan shaking pada kecepatan $300 \mathrm{rpm}$ dan kemudian di sentrifugasi secara singkat dengan micro centrifuge pada kecepatan maksimum. Selanjutnya, RNase (konsentrasi 10 $\mathrm{mg} / \mathrm{ml}$ ) ditambahkan sebanyak 4 ul dan divortex selama 15 detik untuk kemudian dilanjutkan dengan inkubasi pada suhu ruang selama 2 menit. Setelah inkubasi, campuran disentrifugasi secara singkat dengan micro centrifuge pada kecepatan maksimum. Bufer AL sebanyak 200 ul kemudian ditambahkan dan dihomgenkan dengan vortes kemudian diinkubasi (dengan shaking) pada suhu $70{ }^{\circ} \mathrm{C}$ selama 10 menit. Campuran kemudian disentrifugasi secara singkat dengan micro centrifuge pada kecepatan maksimum. Setelah itu 100\% etanol sebanyak 200 ul ditambahkan dan disentrifugasi secara singkat dengan micro centrifuge pada kecepatan maksimum. Campuran tersebut kemudian dengan hati-hati dimasukkan ke dalam kolom QIAamp Mini spin, lengkap dengan tabung penampung, dan disentrifugasi pada kecepatan $6000 \times$ g selama 1 menit. Filtrat yang ditampung dalam tabung penampung kemudian dibuang dan tabung dipasang kembali ke kolom. Bufer AW1 sebanyak 500 ul kemudian dimasukan ke dalam kolom dan disentrifugasi pada kecepatan $6000 \times \mathrm{g}$ selama 1 menit. Filtrat yang ditampung dalam tabung penampung kemudian dibuang dan tabung dipasang kembali ke kolom. Kemudian bufer AW2 sebanyak 500 ul dimasukan dan kemudian disentrifugasi pada kecepatan $20,000 \times$ g selama 3 menit. Sentrifugasi 
diulangi sampai tidak ada lagi filtrat yang keluar ke dalam kolom penampung. Untuk menampung DNA genomik hasil ekstraksi, tabung penampung baru dipasang di kolom. Bufer AE sebanyak 100 ul, yang sebelumnya dipanaskan selama 10 menit pada suhu $60{ }^{\circ} \mathrm{C}$, kemudian ditambahkan ke dalam kolom dan disentrifugasi pada kecepatan $6000 \times$ g selama 1 menit. Proses ini diulangi kembali hingga tidak ada lagi cairan yang keluar dan tertampung dalam tabung penampung. Cairan tersebut adalah DNA genomik dari L. plantarum IIA-1A5. Konsentrasi dan kemurnian DNA genomik kemudian diukur dengan menggunakan UV-Vis spectrophotometer pada panjang gelombang 260 dan 280 nm (Sambrok dan Russel, 2001).

\section{Optimasi Peningkatan Kemurnian DNA Genomik}

Optimasi kemurnian DNA genomik dilakukan pada hasil ekstraksi DNA genomik dari fase pertumbuhan yang memberikan kuantitas DNA paling besar. Optimasi dilakukan pada waktu inkubasi degradasi protein oleh proteinase K. Protokol standar dalam proses ekstraksi adalah lebih dari 1 jam inkubasi. Dalam penelitian ini waktu inkubasi divariasikan dari 2 sampai 12 jam. Konsentrasi dan kemurnian DNA genomik kemudian diukur dengan menggunakan UV-Vis spectrophotometer pada panjang gelombang 260 dan $280 \mathrm{~nm}$. Pada tahap ini, integritas DNA juga dikonfirmasi dengan menggunakan gel agarose electrophoresis dengan konsentrasi sebesar $0.8 \%$ $(\mathrm{w} / \mathrm{v})$. Proses visualisasi DNA genomik dilakukan dengan perendaman agarose setelah proses elektroforesis dalam ethidium bromide dan divisualisasi dengan menggunakan lampu UV.

\section{HASIL DAN PEMBAHASAN}

\section{Fase Pertumbuhan Terbaik untuk Ekstraksi DNA Genomik}

Isolasi biomolekul dari mikroorganisme secara umum bisa dilakukan pada setiap fase pertumbuhannya. Akan tetapi untuk mendapatkan hasil yang optimal, banyak peneliti memilih fase pertumbuhan tertentu untuk proses ekstraksi. DNA dari mikroorganisme bisa diperoleh dari setiap titik fase pertumbuhan bakteri, akan tetapi populasi sel dan keberadaan metabolit primer maupun sekunder lainnya bisa mempengaruhi jumlah dan kualitasnya (Wright et al., 2017). Selain itu, setiap mikroorganisme, termasuk bakteri, memiliki kompleksitas molekuler sendiri dengan kondisi media tumbuh yang berbeda-beda sehingga memungkinkan kondisi optimumnya berbeda dengan yang lainnya (Utnes et al., 2015). Atas dasar tersebut, ekstraksi DNA genomik $L$. plantarum IIA-1A5 dilakukan pada fase pertumbuhan yang berbeda. Kurva pertumbuhan L. plantarum IIA-1A5 yang didapatkan pada penelitian ini disajikan pada Gambar 1 .

Gambar 1 menunjukkan bahwa L. plantarum IIA1A5 setidaknya memiliki 3 fase pertumbuhan yang jelas: fase adaptasi, fase eksponensial dan fase stasioner. Fase adaptasi berlangsung cukup pendek yakni sekitar 2 jam saja. Hal ini mungkin karena bakteri sudah di pre-culture dengan media yang sama selama proses penyegaran. Selanjutnya, fase eksponensial mulai terlihat dari jam ke-2 sampai jam ke-18, atau jam ke-20. Setelah itu, densitas bakteri terlihat konstan sehingga diasumsikan memasuki fase stasionari sampai sekitar jam ke-36. Setelah itu nilai $\mathrm{OD}_{600}$ terlihat menurun yang mengindikasikan fase pertumbuhan memasuki fase kematian. Meskipun demikian, penurunan $\mathrm{OD}_{600}$ pada periode ini tidak begitu signifikan sehingga kami tidak begitu yakin adanya pergeseran fase pertumbuhan di periode ini. Perlu dicatat bahwa penggunaan metode spektroskopi dalam menentukan kurva pertumbuhan memang menjadi perdebatan karena ketidak mampuannya membedakan antara sel hidup dan sel mati. Akan tetapi banyak penelitian menunjukan keberhasilan identifikasi fase kematian dengan menggunakan metode spektroskopi ini (Pan et al., 2014; Duedu dan French, 2017). Hal ini berdasarkan asumsi bahwa sel bakteri yang mati akan diikuti oleh proses auto lisis sel yang menyebabkan sifat spektroskopisnya, pada panjang gelombang tertentu, berbeda dibandingkan dengan sel hidup. Proses auto lisis itu umumnya terjadi pada bakteri Gram positif. Di sisi lain, bakteri Gram negatif akan mengalami pembengkakkan (swelling) sebelum mati

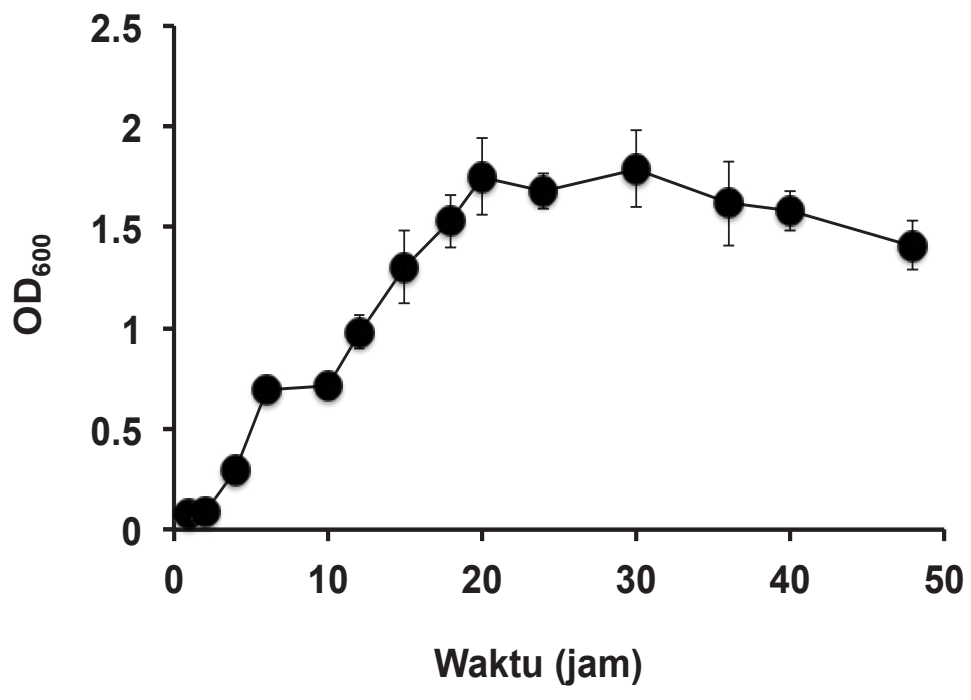

Gambar 1. Kurva pertumbuhan L. plantarum IIA-1A5 
yang mendorong sifat spektroskopisnya berubah. Selain itu, asumsi lainnya adalah sel-sel yang mati akan mendominasi populasi pada fase kematian. Sel-sel mati tersebut akan mengendap (precipitated) yang kemudian mempengaruhi absorbansi dari suspensi tersebut. Asumsi-asumsi tersebut menyebabkan metode spektroskopi dengan $\mathrm{OD}_{600}$ berhasil menentukan fase pertumbuhan bakteri pada beberapa studi (Duedu dan French, 2017).

Penggunaan metode spektroskopi $\mathrm{OD}_{600}$ dalam penelitian ini juga menghasilkan kurva pertumbuhan yang agak berbeda dibandingkan dengan Mutmainna (2017). Mutmainna (2017) menggunakan teknik viable count untuk menentukan populasi bakteri pada setiap titik waktu pengamatan. Di samping itu, penelitian ini menggunakan aerasi dengan kecepatan rendah (100 rpm) selama proses inkubasi sehingga proses pertumbuhannya berbeda dengan Mutmainna (2017) yang tidak menggunakan aerasi. Penggunaan aerasi ini didasarkan pada banyak hasil penelitian yang menunjukkan bahwa kelompok L. plantarum bukan merupakan jenis anaerobic obiligat (Watanabe et al., 2012). Tujuan utama eksperimen fase pertumbuhan dalam penelitian ini adalah untuk mendapatkan DNA yang cukup dalam waktu yang sesingkat-singkatnya sehingga teknik spektroskopi $\mathrm{OD}_{600}$ ini dirasa cukup untuk digunakan dalam penelitian ini. Bahkan secara umum, fase pertumbuhan yang diperoleh dalam penelitian ini mirip dengan hasil Kormin et al. (2001) yang juga menggunakan teknik spekstroskopi untuk menentukan fase pertumbuhan L. plantarum BS2.

Berdasarkan fase pertumbuhan di Gambar 1, ekstraksi DNA dilakukan pada satu interval waktu yang mewakili setiap fase pertumbuhan tersebut. Fase kematian tidak dilibatkan dalam eksperimen ini karena tidak begitu jelas pada fase pertumbuhan. Di samping itu, fase kematian bakteri sudah banyak disarankan untuk tidak dijadikan titik pengambilan sampel dalam ekstraksi DNA. Hasil ekstraksi DNA genomik dari setiap fase pertumbuhan yang berbeda disajikan pada Table 1.

Table 1 menunjukkan bahwa rendemen DNA (yield) berbeda antara satu fase dengan yang lainnya. Fase stasioner menghasilkan DNA yang paling tinggi dibandingkan dengan dua fase lainnya. Hal ini disebabkan karena densitas sel pada fase ini paling maksimum yang mengindikasikan jumlah sel sebagai penghasil DNA lebih tinggi. Pada fase adaptasi, jumlah sel masih minimum sehingga jumlah DNA yang diperoleh dari proses ekstraksi jauh lebih sedikit dari fase lainnya. Meskipun demikian, kemurnian DNA genomik yang diperoleh dari setiap fase pertumbuha tersebut sangat fluktuatif. Rasio 260/280 menunjukkan bahwa DNA genomik yang diperoleh dari fase adaptasi relatif murni. Rasio 260/280 yang diperoleh dari fase tersebut berada dalam rentang ideal $(1,80-2,00)$ untuk WGS dengan menggunakan platform PacBio. Rasio ini menunjukkan derajat kontaminasi protein pada DNA genomik yang diperoleh (Sambrook dan Russel, 2001). Sementara itu, rasio $260 / 280$ pada dua fase pertumbuhan lainnya (Tabel 1) berada di luar rentang rasio ideal. Pada fase eksponensial, sintesis protein berlangsung maksimum karena sel sedang dalam fase pertumbuhan. Di samping itu, metabolit primer dan sekunder yang melibatkan protein juga meningkat. Hal ini mendorong rendahnya rasio 260/280 yang dihasilkan pada fase eksponensial ini. Sementara itu, rasio pada fase stasioner lebih baik dari fase eksponensial, tetapi masih lebih rendah dibandingkan dengan rasio ideal. Hal ini karena jumlah protein yang dihasilkan pada fase ini juga tergolong tinggi, meskipun tidak setinggi pada fase eksponensial, karena laju pertumbuhan lebih lambat dari fase adaptasi.

Sebaliknya, rasio 260/230 menunjukan kontaminasi DNA genomik dari komponen-komponen garam $(\mathrm{NaCl})$, EDTA, karbohidrat, fenol, atau senyawa organik sel lainnya yang menyerap panjang gelombang $230 \mathrm{~nm}$ (Sambrook dan Russel, 2001). Rasio dari 260/230 yang umumnya diterima untuk kemurnian DNA genomik di bawah platform WGS PacBio adalah 2,0. Tabel 1 menunjukkan bahwa semua fase pertumbuhan adaptasi L. plantarum IIA-1A5 menghasilkan DNA genomik dengan rasio 260/230 jauh di luar rasio ideal. Sementara itu, fase pertumbuhan eksponensial dan stasioner menghasilkan rasio 260/230 yang mendekati fase ideal. Secara kasar, pola rasio 260/230 yang diperoleh dari penelitian ini berbeda dengan rasio 260/280, hal ini karena komponen yang mempengaruhi rasio 260/230 bukan saja berasal dari sel itu sendiri, tetapi juga dari kit ekstraksi yang digunakan.

Secara umum, dengan mengacu kepada parameter rendemen, rasio 260/280 dan 260/230, tidak ada fase pertumbuhan yang memenuhi standar kuantitas dan kualitas yang diperlukan. Dalam hal ini, pemilihan fase pertumbuhan yang menghasilkan tingkat rendemen yang paling tinggi dipilih untuk proses optimasi berikutnya. Hal ini berdasarkan fenomena trade-off dalam proses purifikasi biomolekul yang selalu menunjukkan penurunan nilai rendemen sebagai konsekuensi peningkatan kemurnian biomolekul tersebut, dan sebaliknya (Muller-Spath et al., 2015). Hasilnya, fase stasioner kemudian (dengan nilai rendemen paling tinggi) diputuskan sebagai titik pemanenan sel untuk proses ekstraksi DNA.

\section{Peningkatan Kemurnian DNA}

Hasil ekstraksi DNA dari fase pertumbuhan secara umum menunjukkan dua hal utama. Pertama, rendemen DNA yang mencukupi untuk proses WGS. Kedua, kemurnian DNA yang masih harus ditingkatkan, terutama pada rasio 260/280. Dari sisi kemurnian, rasio 260/230

Tabel 1. Kualitas DNA genomik dari fase pertumbuhan yang berbeda

\begin{tabular}{lccc}
\hline Fase & Rendeman DNA $(\mu \mathrm{g})$ & $260 / 280$ & $260 / 230$ \\
\hline Adaptasi & $38,23 \pm 5,10$ & $1,83 \pm 0,11$ & $1,03 \pm 0,08$ \\
Eksponensial & $123,32 \pm 23,09$ & $0,98 \pm 0,08$ & $1,97 \pm 0,08$ \\
Stasioner & $230,21 \pm 9,72$ & $1,38 \pm 0,06$ & $2,34 \pm 0,16$ \\
\hline
\end{tabular}




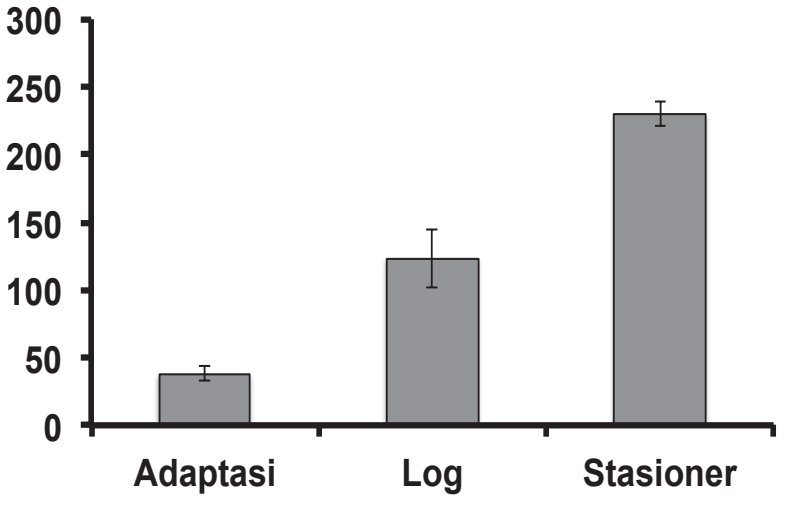

Gambar 2. Rendemen DNA genomik dari fase pertumbuhan yang berbeda

(Table 1) tidak begitu serius dan cukup dekat dengan rasio ideal. Oleh karena itu, peningkatan kemurnian diarahkan pada upaya peningkatan 260/280 dengan menambahkan proteinase K pada waktu inkubasi yang berbeda-beda.

Hasil yang disajikan pada Gambar 2 menunjukkan bahwa terdapat hubungan yang berbeda antara lama inkubasi proteinase K dengan rasio 260/280 atau 260/230. Rasio 260/280 menunjukkan tendensi yang semakin meningkat seiring dengan peningkatan waktu inkubasi proteinase $\mathrm{K}$. Hal ini mudah difahami karena semakin lama masa inkubasi, semakin besar peluang proteinase $\mathrm{K}$ untuk mendegradasi komponen-komponen protein dalam sampel, sehingga konsentrasi akhirnya menurun. Mengacu kepada rasio ideal 260/280 (1,80 - 2,20), lama inkubasi yang bisa menghasilkan rasio 260/280 yang mendekati rentang ideal adalah rentang 7,5 sampai 10 jam inkubasi.

Sebaliknya, lama inkubasi cenderung menurunkan rasio 260/230, meskipun laju penurunan tidak sebesar laju peningkatan $260 / 280$. Proteinase K sebenarnya tidak memiliki hubungan langsung dengan komponen-komponen yang berperan dalam absorbansi panjang gelombang $230 \mathrm{~nm}$, sehingga pola peningkatan 260/230 sebenarnya adalah hal yang tidak diharapkan. Akan tetapi salah satu dugaan dibalik fenomena ini adalah degradasi kontaminan protein oleh proteinase $\mathrm{K}$ mungkin menghasilkan senyawasenyawa fenol atau gugus ring lainnya yang berkontribusi kepada peningkatan absorbansi pada $230 \mathrm{~nm}$. Selain itu, beberapa ion garam yang terikat oleh protein juga menjadi terlepas setelah proses degradasi sehingga menjadi bebas dan meningkatankan absorbansi pada $230 \mathrm{~nm}$. Qamar et al. (2017) menyatakan bahwa tahapan proses ekstraksi DNA yang paling mempengaruhi rasio 260/230 adalah tahap pencucian dengan 70\% (v/v) etanol. Meskipun demikian, peningkatan rasio 260/230 tidak begitu serius menggeser rasio tersebut di luar nilai ideal. Gambar 2 menunjukkan bahwa secara umum inkubasi dari rentang 5 sampai 12 jam masih menghasilkan rasio 260/230 yang ideal.

Jika dua rasio 260/280 dan 260/230 digabungkan, maka lama inkubasi yang bisa menghasilkan dua rasio tersebut dalam rentang ideal adalah 7,5 sampai 10 jam. Rasio 260/280 yang dihasilkan dalam masa inkubasi ini adalah 1,83-2,02, sedangkan rasio 260/230 yang dihasilkan adalah 2,21-1,98. Sesuai dugaan, Gambar 3 juga

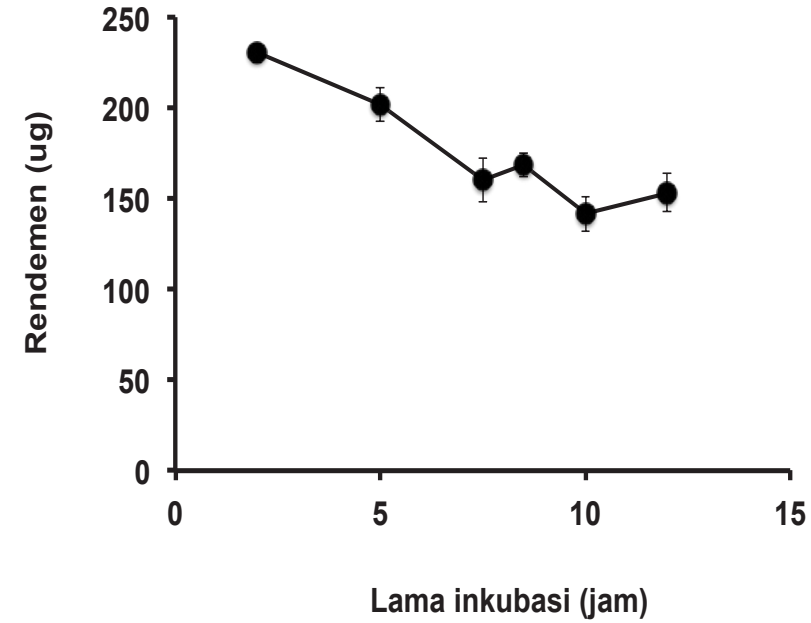

Gambar 3. Rendemen DNA genomik yang dihasilkan dari lama inkubasi yang berbeda

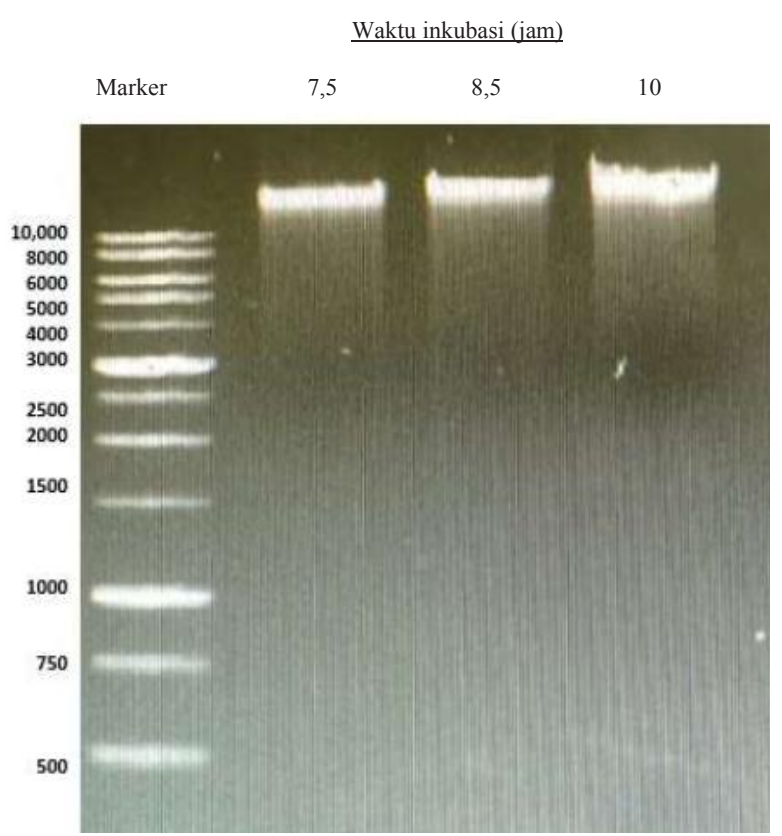

Gambar 4. Visualisasi DNA genomik dengan 0,8\% gel agarose

menunjukkan penurunan rendemen DNA genomik seiring dengan lama inkubasi. Penurunan tajam terjadi pada rentang inkubasi selama 2 sampai 7.5 jam. Setelah itu, penurunan nilai rendemen DNA genomik tidak begitu besar, meskipun tetap terjadi. Secara umum, rendemen DNA yang dihasilkan dari masa inkubasi proteinase $\mathrm{K}$ yang berbeda-beda tersebut masih lebih besar dari jumlah DNA yang dibutuhkan untuk proses WGS. Dalam hal ini, pemilihan masa inkubasi 7,5 sampai 10 jam bisa diterima untuk mendapatkan DNA genomik dengan jumlah dan kemurnian yang memenuhi standar WGS. Pemilihan periode inkubasi ini juga didukung oleh hasil visulasiasi DNA genomik dengan elektroforesis agarose (Gambar 4). Hasil elektroforesis menunjukan bahwa integritas DNA genomik hasil ekstraksi terlihat sangat baik dengan pita yang sangat jelas dan kontaminasi RNA yang tidak terlihat dalam gel (minimal). Visualisasi ini 
memenuhi syarat minimal untuk WGS di bawah platform PacBio yang memerlukan minimum kontaminasi RNA dan stabilitas DNA genomik.

\section{KESIMPULAN}

Inkubasi selama 7.5 sampai 10 jam direkomendasikan sebagai masa inkubasi terbaik untuk bisa mendapatkan DNA genomik L. plantarum IIA-1A5 yang mencukupi baik secara kuantitas maupun kualitas.

\section{DAFTAR PUSTAKA}

Arief, I. I., B. S. L. Jenie, M. Astawan, K. Fujiyama, \& A. B. Witarto. 2015a. Identification and probiotic characteristics of lactic acid bacteria isolate from Indonesian local beef. Asian J Anim Sci. 9(1): 25-36.

Arief, I. I., C. Budiman, B. S. L. Jenie, E. Andreas, \& A. Yuneni. 2015b. Plantaricin IIA-1A5 from Lactobacillus plantarum IIA-1A5 displays bactericidal activity against Staphylococcus aureus. Benef Microbes. 6(4): 603-613.

Arief, I. I., Jakaria, T. Suryati, Z. Wulandari, \& E. Andreas. 2013. Isolation and characterization of plantaricin produced by Lactobacillus plantarum Strain (IIA-1A5, IIA-1B1, IIA-2B2). Med Pet. 36(2): 91-100.

Azcarate-Peril, M. A., R. Tallon, \& T. R. Klaenhammer. 2009. Temporal gene expression and probiotic attributes of Lactobacillus acidophilus during growth in milk. J. Dairy Sci. 92: 870-886.

Duedu, K. O., \& C. E. French. 2017. Data for discriminating dead/live bacteria in homogenous cell suspensions and the effect of insoluble substrates on turbidimetric measurements. Data in Brief. 12: 169-174.

FAO/ WHO. 2002. Guidelines for the evaluation of probiotics in food. Report of Joint FAO/WHO Working Group on drafting Guidelines for the evaluation of probiotics in food. London Ontario, Canada.

Fleischmann, R. D., M. D. Adams, O. White, R. A. Clayton, E. F. Kirkness, A. R. Kerlavage, C. J. Bult, J-F. Tomb, B. A. Dougherty, \& J. M. Merrick. 1995. Whole-genome random sequencing and assembly of Haemophilus influenzae Rd. Science. 269: 496-512.

Fraser, C. M., J. D. Gocayne, O. White, M. D. Adams, R. A. Clayton, R. D. Fleischmann, C. J. Bult, A. R. Kerlavage, G. Sutton, \& J. M. Kelley. 1995. The minimal gene complement of Mycoplasma genitalium. Science. 270: 397-404

Kormin, S., G. Rusul, S. Radu, \& F. H. Ling. 2001. Bacteriocin-producing lactic acid bacteria isolated from traditional fermented food. Malays J Med Sci. 8(1): 63-68.

Land, M., L. Hauser, S. R. Jun, I. Nookaew, \& M. R. Leuze. 2015. Insights from 20 years of bacterial genome sequencing. Funct Integr Genomics. 15: 141-161.

Lebeer, S., J. Vanderleyden, \& S. C. D. De Keersmaecker. 2008. Genes and molecules of lactobacilli supporting probiotic action. Microbiol Mol Biol Rev. 72(4): 728764.

Müller-Späth, T., N. Ulmer, L. Aumann, C. Kennedy, \& M. Bavand. 2015. Twin-column cation-exchange chromatography for the purification of biomolecules. BioPharm Int. 28(4): 32-36.

Mutmainna, Andi. 2017. Pertumbuhan dan produksi senyawa antimikroba dari Lactobacillus plantarum IIA-1A5 pada media whey keju. Tesis. Sekolah Pascasarjana, Institut Pertanian Bogor, Bogor.

Pan, H., Y. Zhang, G. X. He, N. Katagori, \& H. Chen. 2014. A comparison of conventional methods for the quantification of bacterial cells after exposure to metal oxide nanoparticles. BMC Microbiol. 14(222): 1-11.

Panova, M., H. Aronsson, R. A. Cameron, P. Dahl, A. Godhe, U. Lind, O. O. Martinez, R. Pereyra, S. V. M. Tesson, A. L. Wrange, A. Blomberg, \& K. Johannesson. 2016. DNA extraction protocols for whole-genome sequencing in marine organisms. Methods Mol Biol. 1452: 13-44.

Qamar, W., M. R. Khan, \& A. Arafah. 2017. Optimization of conditions to extract high quality DNA for PCR analysis from whole blood using SDS-proteinase K method. Saudi J Biol Sci. 24: 1465-1469.

Salvà-Serra, F., L. Svensson-Stadler, A. Busquets, D. JaénLuchoro, R. Karlsson, E. R. B. Moore, \& M. Gomila. 2018. A protocol for extraction and purification of high-quality and quantity bacterial DNA applicable for genome sequencing: a modified version of the Marmur procedure. Protocol Exchange. 1-4.

Sambrook, J., \& D. W. Russel. 2001. Expression of cloned genes in Escherichia coli (chapter 15). In: Molecular Cloning: A Laboratory Manual. 3th Edition. New York: Cold Spring Harbor Laboratory Press. 15:36-47.

Shendure, J., \& H. Ji. 2008. Next-generation DNA sequencing. Nat Biotechnol 26: 1135-1145.

Siezen, R. J., \& G. Wilson. 2010. Probiotics genomics. Microb Biotechnol. 3(1): 1-9.

Silva, A. P. R. D., D. A. Longhi, F. Dalcanton, G. M. F. de-Aragão. 2018. Modelling the growth of lactic acid bacteria at different temperatures. Braz Arch Biol Technol. 61: 1-11.

Sim, J. H. C., V. Anikst, A. Lohith, N. Pourmand, \& N. Banaeia. 2015. Optimized protocol for simple extraction of high-quality genomic DNA from clostridium difficile for whole-genome sequencing. J Clin Microbiol. 53(7): 2329-2331.

Statista. 2017. Estimated value of probiotics market worldwide from 2017 to 2022 (in billion U.S. dollars). https://www.statista.com/statistics/821259/globalprobioticsl-market-value. [21 Januari 2019].

Utnes, A. L. G., V. Sørum, N. Hülter, R. Primicerio, J. Hegstad, J. Kloos, K. M. Nielsen, \& P. J. Johnsen. 2015. Growth phase-specific evolutionary benefits of natural transformation in Acinetobacter baylyi. The ISME Journal. 9: 2221-2231.

Watanabe, M., S. V. D. Veen, \& T. Abeea. 2012. Impact of respiration on resistance of Lactobacillus plantarum WCFS1 to acid stress. Appl Environ Microbiol. 78(11): 
4062-4064.

Wright, M. H., J. Adelskov, \& A. C. Greene. 2017. Bacterial DNA extraction using individual enzymes and phenol/ chloroform separation. J Microbiol Biol Educ. 18(2): 1-3.

Zhu, Q., Q. Hu, L. Shepherd, J. Wang, L. Wei, C. Morrison, J. M. Conroy, S. T. Glenn, W. Davis, M. L. Kwan, I. J. Ergas, J. M. Roh, L. H. Kushi, C. B. Ambrosone, S. Liu, \& S. Yao. 2016. The impact of DNA input amount and DNA source on the performance of whole-exome sequencing in cancer epidemiology. Cancer Epidemiol Biomarkers Prev. 24(8): 1207-1213. 